УДК [378.02:373.3.011.3-051]:005.336.2

DOI: $10.35619 /$ iiu.v1i11.261

Третяк Оксана

кандидат педагогічних наук, доцент кафедри педагогіки початкової освіти Рівненського державного гуманітарного університету, м. Рівне, Україна ORCID: 0000-0002-4558-2863 e-mail: ksenijat2017@gmail.com

Міщеня Оксана кандидат педагогічних наук, доцент кафедри педагогіки початкової освіти Рівненського державного гуманітарного університету, м. Рівне, Україна ORCID: 0000-0003-3041-1575 e-mail: oksanamishchenia@gmail.com

\title{
ПЕДАГОГІЧНА РЕФЛЕКСІЯ У КОНТЕКСТІ ПРОФЕСІЙНОӤ КОМПЕТЕНТНОСТІ МАЙБУТНЬОГО ВЧИТЕЛЯ ПОЧАТКОВОЇ ШКОЛИ, ФАХІВЦЯ 3 ІНКЛЮЗИВНОЇ ОСВІТИ
}

\begin{abstract}
Анотація. За результатами аналізу теоретичних джерел обгрунтовано сутність понять «рефлексія», «педагогічна рефлексія», «професійна рефлексія», «професійна компетентність майбутнього вчителя початкової школи» та «професійна компетентність вчителя початкових класів у сфері інклюзивного навчання» та визначено місце і роль педагогічної рефлексії у структурі професійної компетентності майбутнього вчителя початкової школи, фахівця з інклюзивної освіти. Розкрито необхідність формування рефлексивної компетентності майбутнього вчителя початкової школи, фахівця з інклюзивної освіти. З'ясовано, що сформованість педагогічної рефлексії є регулятором особистісних досягнень, пошуку особистісного сенсу у спілкуванні 3 іншими, а також спонукає до самопізнання, професійного зростання, вдосконалення майстерності, творчої діяльності, успішної реалізації реформи освіти, а також запобігає професійному вигоранню педагога. Подано класифікацію рефлексії за типами, видами практик, змістом, формою діяльності, цілями. Представлено форми та методи використання педагогічної рефлексії в освітньому процесі професійної підготовки фахівців початкової освіти, інклюзивної освіти; наведено приклади окремих вправ.

Ключові слова: рефлексія, педагогічна рефлексія, професійна рефлексія, рефлексивна компетентність майбутнього вчителя початкової школи, фахівця 3 інклюзивної освіти.
\end{abstract}

Постановка проблеми. Модернізація системи педагогічної освіти в умовах Нової української школи потребує переосмислення i пошуку нових концептуальних підходів до професійної підготовки майбутніх учителів, фахівців 3 інклюзивної освіти. Сучасна школа покликана формувати всебічно розвинену особистість, здатну до критичного мислення; патріота з активною позицією, який діє згідно морально-етичних принципів, здатний приймати відповідальні рішення, поважати гідність і права людини; інноватора, здатного змінювати навколишній 
світ, розвивати економіку за принципами сталого розвитку, конкурувати на ринку праці, навчатися впродовж життя (Міністерство освіти і науки України, 2016).

Ефективність реалізації поставлених завдань, які зазначені у новому Законі України «Про освіту», Державному стандарті початкової освіти, Концепції Нової української школи, залежить від висококваліфікованих фахівців, готових сприймати все нове й прогресивне, відкритих до накопичення та осмислення нових ідей, здатних до саморозвитку, самовизначення та самореалізації.

Відтак, пошук способів особистісного та професійного зростання майбутніх фахівців вимагає детального аналізу рефлексивного компонента як важливої складової професійної компетентності майбутнього вчителя початкової школи, фахівця з інклюзивної освіти.

Аналіз останніх досліджень 3 проблеми. Дослідження щодо сутності рефлексії розкрито у працях А. Бізяєва, А. Гурєєва, Г. Дегтяр, М. Заброцького, А. Карпова, О. Кононко, С. Максименко, В. Петровського, А. Петруліте, Н. Пов'якель, В. Семиченко та ін. Досліджено роль рефлексивних процесів у професійному становленні вчителів мистецьких дисциплін (В. Орлов), фізичної культури (А. Максимов), іноземної мови (А. Веремчук), майбутнього вчителя початкової школи (Ю. Бабаян, К. Нор); особливості формування рефлексивної компетентності студентів в освітньому процесі педагогічного коледжу (Ю. Кушеверська); процес розвитку педагогічної рефлексії у фаховій підготовці майбутнього вчителя (Н. Крашеніннікова); здатність до професійної рефлексії як необхідний критерій готовності до інклюзивної діяльності (А. Колупаєва, 3. Шевців) тощо.

Мета статті - розкрити сутність педагогічної рефлексії та обгрунтувати особливості їі формування у процесі фахової підготовки майбутнього вчителя початкової школи, фахівця з інклюзивної освіти.

Виклад основного матеріалу дослідження. Формування компетентностей $\epsilon$ ключовим результатом усіх ланок освіти. Не $є$ виключенням і заклади вищої освіти, мета яких - формування професійної компетентності майбутніх фахівців.

Під поняттям «професійна компетентність майбутнього вчителя початкових класів» ми розуміємо інтегральне особистісне утворення, яке вміщує комплекс поліфункціональних професійних знань, практичних умінь і навичок, особистісних якостей та набутого квазіпрофесійного досвіду із залученням можливостей сучасної кредитно-модульної системи професійної підготовки студентів у педагогічному 3ВО, що забезпечує іiі успішну реалізацію у майбутній професійній діяльності (Третяк, 2014). «Професійна компетентність учителя початкових класів у сфері інклюзивного навчання - це синтез знань, умінь та навичок. необхідних для успішного здійснення соціально-педагогічної діяльності, зміст якої розкривається через комплекс особистісно значущих якостей та професійних компетентностей i компетенцій» (Шевців, 2019, с. 69).

Однією з важливих особистісно значущих якостей учителя початкової школи, в тому числі й учителя інклюзивного навчання, $\epsilon$ рефлективність як уміння самоусвідомлювати результати власної професійної діяльності та саморозвиватися. Тому інтегруючим компонентом у структурі професійної компетентності майбутнього вчителя початкової школи, фахівця 3 інклюзивної освіти на нашу думку, $€$ рефлексивна компетентність (самооцінка, самоконтроль, самовдосконалення майбутнього фахівця).

Розглянемо сутність понять «рефлексія», «педагогічна рефлексія», «професійна рефлексія». Термін «рефлексія» (лат. reflexio - «звернення назад»; англ. to reflect 
Інноватика у вихованні. Випуск 11. Том 1. 2020.

upon - «розмірковувати над») означає осмислення людиною передумов, закономірностей і механізмів власної діяльності і поведінки.

Рефлексія у Великому тлумачному словнику сучасної української мови визначається як 1) самоаналіз, роздуми людини над власним душевним станом; 2) в ідеалістичній філософії - відображення, а також дослідження процесу пізнання (Великий тлумачний словник сучасної української мови, 2004).

У філософському словнику рефлексія визначається як принцип людського мислення, який спрямовує іiі на осмислення й усвідомлення власних форм i передумов; предметний розгляд самого знання, критичний аналіз його змісту i методів пізнання; діяльність самопізнання, яка розкриває внутрішню побудову і специфіку духовного світу людини (Сучасний філософський словник, с. 579).

Низка науковців під рефлексією розуміє:

- $\quad$ форму теоретичної діяльності людини, спрямовану на осмислення власних дій і вчинків. Самоаналіз та самооцінка, які засновані на рефлексії, забезпечують контроль еталоном, взірцем, який виступає як критеріальна основа оцінної діяльності (Попков та Коржуєв);

- $\quad$ здатність зростаючої особистості усвідомлювати свої особливості і те, як вони сприймаються іншими, а також будувати свою поведінку 3 урахуванням можливих реакцій інших (у першу чергу, авторитетних) (Кононко);

- ідеальну форму діяльності людини, спрямовану на саму себе, роздуми особистості над власною поведінкою та духовним світом у цілому, в результаті чого формується певний «Я-образ» (Петруліте);

- активне, цілеспрямоване усвідомлення особистістю власних характеристик як детермінант конкретної поведінки (Бабаян та Нор, 2011).

Отже, рефлексія є передумовою здатності людини до саморегуляції. Вона передбачає розвиток в індивіда, з одного боку, вміння критично ставитися до себе, а 3 іншого, усвідомлювати свої недоліки і ставитися до них без почуття провини або сорому, сприймаючи себе як особистість, яка може самоудосконалюватися.

Педагогічна рефлексія дає можливість вчителю подивитись на свою працю 3 позиції іншої людини, виробити відповідне ставлення до своєї професії, визначає ставлення вчителя до себе як до суб'єкта професійної діяльності. Здатність порівнювати, співставляти самосвідомість 3 оцінками інших учасників взаємодії допомагає учителю усвідомити те, як до нього ставляться і як його оцінюють інші - вихованці, колеги, батьки (Лук'янова, 2001). Позиція вчителя, яка спрямована на постійний «зворотній зв'язок», на вміння інтерпретувати отриману інформацію 3 позиції того, хто навчається, оцінювати результативність і доцільність педагогічних рішень $є$ важливою умовою розвитку професіоналізму педагога (Лук'янова, 2001, с. 59).

Р. Тур (2004) формулює педагогічну рефлексію як усвідомлення вчителем себе самого суб'єктом діяльності: своїх особливостей, здібностей, того, як його сприймають учні, батьки, колеги, адміністрація.

У психолого-педагогічній літературі науковці (І. Зязюн, С. Климов, А. Маркова, В. Орлов, О. Пєхота, О. Савченко, В. Семиченко та ін.) акцентують увагу на важливості рефлексії в процесі професійного становлення майбутнього фахівця, як стрижневого компонента, що визначає співвідношення між сенсом життя i професійною діяльністю.

В. Петровський (2008), розглядаючи професійну рефлексію у структурі професійної компетентності педагога, виокремлює такі ії елементи: усвідомлення педагогом справжніх мотивів своєї діяльності; вміння відрізнити власні 
ускладнення і проблеми від ускладнень і проблем вихованців; оцінка наслідків власних особистісних впливів на вихованців і вміння бачити себе в дзеркалі життя інших людей; здатність до емпатії і децентрації (здатність до сприймання точки зору іншої людини). С. Чорний (2002) вважає, що в цілому професійна рефлексія $\epsilon$ психологічним механізмом, за допомогою якого педагог постійно виявляє ступінь розбіжності між особистісними уявленнями про ефективного та успішного педагога в цілому (ідеальний образ педагога), уявлення про себе як педагога (ідеальний образ: Я - ідеальне педагога) та реальним рівнем успішності та ефективності (Я - реальне педагога).

Професійна рефлексія - це виведення на когнітивний рівень, об'єктивація суб'єктивних переживань, пов'язаних із професійною діяльністю. Адекватне знання ступеня та характеру розбіжностей між ідеальними образами та реальною ситуацією «Я - в професії» $є$ постійно діючим стимулом до самоудосконалення, особистого та професійного зростання педагога, в цьому і полягає значення професійної рефлексії (Радченко, 2006).

Виникає необхідність формування рефлексивної компетентності майбутнього вчителя початкової школи, фахівця $з$ інклюзивної освіти, яка є підгрунтям його самовдосконалення.

Рефлексивний компонент у структурі професійної компетентності майбутнього вчителя початкової школи реалізується в умінні свідомо контролювати результати своєї діяльності і рівень власного розвитку, особистісних досягнень; сформованість таких важливих для педагога якостей i властивостей, як креативність, ініціативність, спрямованість на співпрацю, співтворчість, впевненість у собі, схильність до самоаналізу, здатність до імпровізації, передбачення, творчого уявлення, а також професійно-значущих знань, умінь і навичок (Калінін, 2005; Третяк, 2014).

Разом з тим, рефлексивний компонент інклюзивної компетентності виявляється в здатності усвідомлювати основи власної діяльності, у ході якої оцінюються та переосмислюються свої здібності, особистісні досягнення, а також у свідомому контролі результатів професійних дій, аналізі реальних ситуацій. У системі інклюзивної компетентності рефлексія витлумачена як здатність до аналізу в процесі професійної діяльності, що спрямована на інклюзію дітей і молоді 3 особливими потребами в соціумі загальноосвітнього закладу та передбачає аналіз стану реалізації ідей процесу інклюзії, власного досвіду й досвіду колег у досягненні інклюзії дітей $і$ молоді 3 особливими потребами в соціумі загальноосвітнього закладу в процесі професійної діяльності, вибір оптимального варіанта розв'язання різних соціально-педагогічних ситуацій у процесі інклюзіі; адекватне оцінювання результатів власної соціально-педагогічної діяльності, уміння визнавати власні помилки і здатність їх усувати; потреби в професійному й особистісному зростанні та підвищенні рівня інклюзивної компетентності (Бондар, 2014).

Під рефлексивною компетентністю Ю. Бабаян та К. Нор (2011) розуміють вдумливе та відповідальне ставлення вчителя-професіонала до своєї роботи, що грунтується на постійному осмисленні своєї діяльності та ії результатів в інтересах інших людей. Недостатній рівень іiі прояву перешкоджає успішній реалізації реформи освіти.

Формуючи професійну рефлексію у майбутнього вчителя початкової школи, фахівця 3 інклюзивної освіти, необхідно пам'ятати про цілеспрямований, системний і організований процес, який важливо розпочинати з першого курсу навчання у ЗВО. 
Професіограма рефлексивного педагога включає такі вміння: бачити проблему і формулювати відповідні цілі і завдання педагогічної діяльності; враховувати особливості взаємодіючих суб'єктів і умов, у яких виникла та чи інша ситуація; уміння робити предметом аналізу усі дії, які починаються і проєктуються, особистісні якості і компетенції, що проявляються, домінантні цілі і мотиви; узагальнювати досвід своєї практичної роботи і використовувати у своїй практиці досвід колег; уміння знаходити різні шляхи розв'язання педагогічної ситуації, проєктувати різні моделі поведінки, робити обгрунтований вибір; об'єктивно оцінювати педагогічні факти, явища, рівень власної компетентності, професійнозначимі особистісні якості; адаптовувати, доповнювати і змінювати навчальний план, програму, форми і методи навчання відповідно до конкретних умов з метою досягнення оптимальних результатів; визначати і спрогнозувати перспективи i напрями власного самоудосконалення тощо (Ю. Бабаян та К. Нор, 2011).

Отже, рефлексивна компетентність дає змогу педагогу осмислити, зрозуміти емоційний та особистісний стан суб'єктів навчання, осіб 3 особливими освітніми потребами та включити їх в освітній процес.

Існує декілька класифікацій рефлексії: за змістом - символічна, усна, письмова; за формою діяльності - колективна, групова, фронтальна та індивідуальна; за цілями - рефлексія діяльності; рефлексія змісту навчального матеріалу; рефлексія настрою та емоційного стану; за видами практики - рефлексія щодо дії: аналіз дій чи думок, які вже мали місце; рефлексія в дії: спонтанне експериментування з новими ідеями; рефлексія для дії: використання інсайтів, отриманих у результаті рефлексії щодо думок чи дій, які відбулися, як керівництво для подальших дій.

Вирізняють 4 типи рефлексії: інтелектуальна - самоусвідомлення власної особи як суб' єкта пізнання; особистісна - самоусвідомлення власної особи як індивіда в цілому; комунікативна - самоусвідомлення власної особи як суб'єкта спілкування; праксеологічна - самоусвідомлення власної особи як суб'єкта професійної діяльності (Радченко, 2006).

Розвиток рефлексивних здібностей у майбутніх фахівців початкової школи варто реалізовувати впродовж усього освітнього процесу в ЗВО. Зокрема, ми формуємо рефлексивну компетентність як під час вивчення навчальних курсів, так i в процесі гурткової роботи, під час проходження педагогічної практики, написання наукових проєктів, дипломних робіт тощо.

Наприклад, під час викладання курсів «Дидактика початкової школи», «Організація інклюзивного навчання в початковій школі» рефлексія виступає ключовим елементом на завершальному етапі кожного заняття та $є$ обов'язковим елементом кожної інтерактивної вправи. На етапі рефлексії студент коротко оцінює роботу, свою участь і самопочуття. Це можуть бути такі вправи:

«Рефлексивний екран». Завдання: висловіть свою думку щодо заняття, вибираючи початок фрази з рефлексивного екрану на дошці.

Сьогодні я дізнався... Було иікаво... Було важко... Я зрозумів, щзо... Тепер я можу... Мене здивувало... Я навчився... Для себе я взяв...

«Анкета-рефлексія».

Чи задоволений ти результатом самої роботи? А процесом? Чому? Якби тобі дали змогу ще раз виконати ї̈, які зміни ти вніс би в хід ї̈ виконання? Чи взявся б ти за роботу, якби міг передбачити ї̈ результат? Якби не взявся, то яку роботу хотів би виконати натомість? Над чим хотів би працювати надалі?

«Знаю - дізнався - хочу дізнатися». Студентам пропонується поставити позначки за допомогою знаків на полях біля тексту або в самому тексті. 
«+» - знаю. «!»- новий матеріал (дізнався). «?»- хочу дізнатися.

«Ресторан». Студентам пропонується уявити, що сьогоднішній день вони провели в ресторані і тепер директор ресторану просить їх дати відповідь на декілька запитань за змістом заняття.

Я з'їв би щее иче... Найбільще мені сподобалося... Я переїв... Будь ласка, принесіть ще...

«Сенкан». Наприклад, тема «Методи навчання»:

Бесіда. Спокійна, відкрита. Розкриває, повідомляє, характеризує. Словесний, діалогічний метод навчання. Розмова.

«Палітра емоцій». Із поданого переліку емоцій, пропонується вибрати три, що відповідають вашому настрою на цей момент: замріяність, співчуття, захоплення, спокій, переживання, радість, легенький смуток, журба, заздрість, злість, роздратування, розчарування, піднесення, бажання творити тощо.

Педагогічна рефлексія спрямована на осмислення й усвідомлення студентами під час лекції чи практичного (лабораторного) заняття ідеї; спроба відобразити те, що сталося $з$ моїм «Я»: «Що я думав? Що відчував? Що придбав? Що мене здивувало? Що я зрозумів?» тощо. Тобто, використовуючи в освітньому процесі педагогічну рефлексію, відповідаючи на поставлені питання, пасивний студент активно включається в освітній процес. Педагогічна рефлексія спонукає до дії, дає зрозуміти: «Що для тебе є важливим? Для чого тобі ці знання? Де ти їх зможеш використати?» I коли теоретичний матеріал переходить в особистісну значущість, студент по-іншому починає його сприймати, йому стає цікаво вчитися, розробляти, мислити, творити.

Методика організації етапу рефлексії передбачає: встановлення фактів (що відбулося; що і навіщо вивчали; які помилки допустили чи могли б допустити); аналіз причин (чому це відбулося; які способи діяльності ми використовували; яким чином досягали мети); виявлення і формулювання результатів рефлексії (ідеї, пропозиції, закономірності, висновки); планування подальших дій.

У роботі гуртка-тренінгу «Професійний розвиток майбутнього вчителя початкової школи», який функціонує в межах діяльності Освітньо-ресурсного центру кафедри педагогіки початкової освіти РДГУ, зі студентами педагогічного факультету практикуємо як окремі вправи рефлексивного характеру, так і тренінги, спрямовані на самоудосконалення майбутнього вчителя початкової школи, фахівця інклюзивної освіти. Формування рефлексивних здібностей відбувається у процесі бесід, рольових ігор, диспутів, перегляду відеороликів, ауторелаксу тощо.

У ході тренінгу створюються такі умови, які вводять майбутніх фахівців початкової школи у рефлексивну позицію щодо себе і своєї майбутньої професійної діяльності, спонукаючи до самоаналізу і осмислення себе у професійно значимій ситуації, до оцінки своїх дій, поглядів, переконань.

На формування рефлексивної компетентності майбутнього вчителя початкової школи та фахівця з інклюзивної освіти під час навчального тренінгу спрямовані такі вправи: «Стілець бажань», «Я - це Я», «Притча про мудреця і метелика», «Подолання звинувачення», «Корзина для сміття», «Мийка», «Повітряна куля», «Мій перший день у школі», «Я можу!» та ін. (Третяк, 2013).

Висновки та перспективи подальших розвідок. Отже, педагогічна рефлексія має стати обов' язковим елементом навчальних занять у закладах освіти всіх рівнів, у тому числі й вищій школі. Рефлексія на занятті - це спільна діяльність викладача та студента, що дозволяє вдосконалювати освітній процес, враховуючи навчальні потреби кожного, в тому числі й осіб з особливими освітніми потребами. 
У результаті пошуку ми виокремили такі переваги рефлексії: здатність до об'єктивної самооцінки; аналіз результатів педагогічної діяльності з різних позицій: рух думки «угору» та «вглиб», від «назовні» до «всередину»; усвідомлення здобутих знань і вмінь; порівняння свого сприйняття 3 думками, поглядами, почуттями інших, коригування певних позицій; набуття вміння рефлексувати в реальному житті, що дуже важливо, особливо для фахівців 3 інклюзивної освіти, усвідомлюючи свої дії та прогнозуючи подальші кроки. Систематичне використання рефлексії під час занять дає можливість викладачу своєчасно побачити реакцію студентів на навчання, внести необхідні корективи в роботу, удосконалювати форми та методи викладання.

Професійна рефлексія включає уміння вибору, проєктування та реалізації тих чи інших професійних маршрутів, уміння професійної самодіагностики, а саме: адекватну оцінку рівня власної професійної майстерності i способів іiі вдосконалення, усвідомлення своєї ролі в діяльності професійного колективу, вміння оцінити можливості виконання запропонованих та самостійно обраних задач різного масштабу та рівня.

\section{СПИСОК ВИКОРИСТАНИХ ДЖЕРЕЛ}

Міністерство освіти і науки України, (2016). Концепція «Нова украӥнська школа»: URL: https://mon.gov.ua/storage/app/media/zagalna\%20serednya/novaukrainska-shkola-compressed.pdf [Дата звернення 9 травня 2020 р.].

Третяк, О. (2014). Формування професійної компетентності майбутнього вчителя початкових класів в умовах кредитно-модульної системи вищого навчального закладу. Кандидат педагогічних наук. Житомирський державний університет імені Івана Франка.

Шевців, 3. (2019). Основи інклюзивної педагогіки. Львів: «Новий світ - 2000». $264 \mathrm{c}$.

Великий тлумачний словник украӥнської мови (2004). В. Т. Бусел (ред.) Київ; Ірпінь: ВТФ «Перун». 1440 с.

Современный философский словарь (2004). Санкт-Петербург: Академический проект. 864 с.

Лукьянова, М. (2001). Психолого-педагогическая компетентность учителя. Педагогика, 10. с. 56-61.

Тур, Р. (2004). Педагогічна рефлексія - основа формування творчого саморозвитку особистості. Управління школою, 13.

Петровский, В. (2008). Состоятельность и рефлексия: модель четырех курсов. Психология. Журнал высшей школы, 5(1), с. 77-100.

Черный, Е. (2002). Инициирование профессиональной рефлексии у педагогов. Практична психологія та соиіальна робота, 3, с. 14-17.

Радченко, А. (2006). Професійна компетентність учителя. Харків: Основа. 86c.

Калінін, В. (2005). Формування професійної компетентності майбутнього вчителя іноземної мови засобами діалогу культур. Кандидат педагогічних наук. Житомирський державний університет імені Івана Франка.

Бондар, Т. (2014). Формування інклюзивної компетентності в умовах інноваційної парадигми освіти. Педагогічні науки: теорія, історія, інноваційні технологіï, 7 (41), с. 153-162.

Бабаян, Ю. та Нор, К. (2011). Формування рефлексивної компетентності майбутнього вчителя початкових класів. Формування професійної компетентності майбутнього вчителя в умовах вищого навчального закладу. С. І. Якименко [ред]. Київ: Видавничий дім «Слово», с. 231-265. 
Третяк, О. (2013). Професійний розвиток майбутнього вчителя початкової школи: навчально-методичний тренінг (для студентів напряму підготовки «Початкова освіта». Рівне: РДГУ. 105 с.

\section{REFERENCES}

Ministerstvo osvity i nauky Ukrainy, (2016). Kontseptsiia "Nova ukrainska shkola" [The Concept of the "New Ukrainian School"]: URL: https://mon.gov.ua/storage/app/media/zagalna\%20serednya/nova-ukrainska-shkolacompressed.pdf [Data o zvernennia 9 travnia 2020 r.]. (in Ukrainian)

Tretiak, O. (2014). Formuvannia profesiinoi kompetentnosti maibutnoho vchytelia pochatkovykh klasiv v umovakh kredytno-modulnoi systemy vyshchoho navchalnoho zakladu [Shaping of professional competence of future elementary school teacher in the Context of the Credit-module System of Higher Educational Institutin]. Kandydat pedahohichnykh nauk. Zhytomyrskyi derzhavnyi universytet imeni Ivana Franka. (in Ukrainian)

Shevtsiv, Z. (2019). Osnovy inkliuzyvnoi pedahohiky [Fundamentals of Inclusive Pedagogy]. Lviv: "Novyi svit - 2000”. 264 s. (in Ukrainian)

Velykyi tlumachnyi slovnyk ukrainskoi movy [Large Explanatory Dictionary of the Ukrainian Language] (2004). V. T. Busel (red.) Kyiv; Irpin: VTF "Perun". 1440 s. (in Ukrainian)

Sovremennyi filosofskii slovar [Modern Philosophical Dictionary] (2004). SanktPeterburh: Akademicheskii proekt. 864 s. (in Ukrainian)

Lukianova, M. (2001). Psykhologo-pedagogicheskaia kompetentnost uchitelia [Psychological and Pedagogical Competence of the Teacher]. Pedagogika, 10. s. 56-61. (in Russian)

Tur, R. (2004). Pedahohichna refleksiia - osnova formuvannia tvorchoho samorozvytku osobystosti [Pedagogical Reflection - the Basis for the Formation of Creative Self-development of the Individual]. Upravlinnia shkoloiu, 13. (in Ukrainian)

Petrovskii, V. (2008). Sostoiatelnost i refleksiya: model chetyrekh kursov [Consistency and Reflection: a Four-course Model]. Psikhologiya. Zhurnal vysshei shkoly, 5(1), s. 77-100. (in Russian)

Chernyi, E. (2002). Initsiirovaniye professionalnoi refleksii u pedagogov [Initiation of Professional Reflection in Teachers]. Praktychna psykholohiia ta sotsialna robota, No 3, s. 14-17. (in Russian)

Radchenko, A. (2006). Profesiina kompetentnist uchytelia [Professional Competence of a Teacher]. Kharkiv: Osnova. 86 s. (in Ukrainian)

Kalinin, V. (2005). Formuvannia profesiinoi kompetentnosti maibutnoho vchytelia inozemnoi movy zasobamy dialohu kultur [Formation of Professional Competence of the Future Foreign Language Teacher by means of Dialogue of Cultures]. Kandydat pedahohichnykh nauk. Zhytomyrskyi derzhavnyi universytet imeni Ivana Franka. (in Ukrainian)

Bondar, T. (2014). Formuvannia inkliuzyvnoi kompetentnosti $v$ umovakh innovatsiinoi paradyhmy osvity [Shaping of Inclusive Competence in the Context of Innovative Paradigm of Education]. Pedahohichni nauky: teoriia, istoriia, innovatsiini tekhnolohii, 7 (41), s. 153-162. (in Ukrainian)

Babaian, Yu. ta Nor, K. (2011). Formuvannia refleksyvnoi kompetentnosti maibutnoho vchytelia pochatkovykh klasiv [Shaping of Reflexive Competence of the Future Elementary School Teacher]. Formuvannia profesiinoi kompetentnosti maibutnoho vchytelia v umovakh vyshchoho navchalnoho zakladu. S. I. Yakymenko [red]. Kyiv: Vydavnychyi dim "Slovo", s. 231-265. (in Ukrainian)

Tretiak, O. (2013). Profesiinyi rozvytok maibutnoho vchytelia pochatkovoi shkoly: 
Інноватика у вихованні. Випуск 11. Том 1. 2020.

navchalno-metodychnyi treninh (dlia studentiv napriamu pidhotovky «Pochatkova osvita») [Vocational Development of Future Elementary School Teacher: Educationalpedagogical Training (for Students of the specialty "Primary education"]. Rivne: RDHU. 105 s. (in Ukrainian)

\section{PEDAGOGICAL REFLEXION IN THE CONTEXT OF THE PROFESSIONAL COMPETENCE OF THE FUTURE PRIMARY SCHOOL TEACHER, SPECIALIST IN INCLUSIVE EDUCATION}

Oksana Tretiak

Candidate of Pedagogical Sciences, Associate Professor at the Department of Primary Education Pedagogy, Rivne State University for the Humanities,

Rivne, Ukraine

ORCID: 0000-0002-4558-2863 e-mail: ksenijat2017@gmail.com

Oksana Mischenia

Candidate of Pedagogical Sciences, Associate Professor at the Department of Primary Education Pedagogy.

Rivne State University for the Humanities,

Rivne, Ukraine

ORCID: 0000-0003-3041-1575

e-mail: oksanamishchenia@gmail.com

Abstract. Modernization of the pedagogical education system in the context of the New Ukrainian school requires a new generation of highly qualified specialists, which are ready to accept everything new and progressive, are open to accumulation and obtaining new ideas, are capable to self-development, self-determination. The need to ensure the search for ways of personal and professional growth of the future elementary school teacher, a specialist in inclusive education, encourages them to form a pedagogical reflection.

On the basis of theoretical sources the essence of the concepts "reflection", "pedagogical reflection", "professional reflection" were substantiated. Based on the interpretation of the concepts "professional competence of future primary school teachers" and "professional competence of elementary school teachers in the field of inclusive education" it determine the place and role of pedagogical reflection in the structure of professional competence of future elementary school teachers and inclusive education specialist. The necessity of formation of reflective competence of the future elementary school teacher, specialist in inclusive education was revealed. Moreover, it was found that the formation of pedagogical reflection is a regulator of personal achievements, the search for personal meaning in communication with others, and encourages self-knowledge, professional growth, skills, creativity, successful implementation of educational reforms, and prevents professional burnout of teachers. Different approaches to the classification of the reflection were presented: according to the types (intellectual, personal, communicative, praxeological), types of practice (reflection on action, reflection in action, reflection after action); content (symbolic, oral, written); forms and goals of activities (collective, group, frontal, individual); forms of teaching (lectures, practical, laboratory classes, trainings, practice), methods of using pedagogical reflection in the educational process of vocational training of elementary education, inclusive education. Some examples of individual exercises were given.

Keywords: reflection, pedagogical reflection, professional reflection, reflexive competence of the future elementary school teacher, specialist in inclusive education.

Стаття надійшла до редакиії 10.05.2020 p. 